

Ukrainian Journal of

Veterinary and Agricultural Sciences

http://ujvas.com.ua

Stepan Gzhytskyi National University of Veterinary Medicine and Biotechnologies Lviv

original article $\mid$ UDC 619.615.637.657 | doi: 10.32718/ujvas1-1.01

Volume 1

Number 1

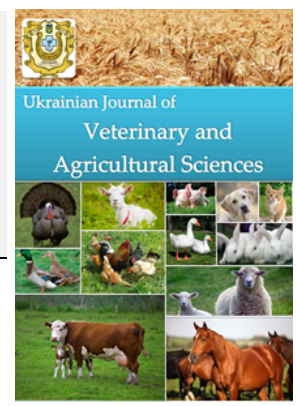

\title{
Preclinical research of the experimental preparation “Ferosel T"
}

\author{
V.B. Todoriuk, V.M. Hunchak, B.V. Gutyj, D.F. Gufriy, I.I. Hariv, R.I. Khomyk, R.O. Vasiv \\ Stepan Gzhytskyi National University of Veterinary Medicine and Biotechnologies Lviv, \\ Pekarska Str., 50, Lviv, 79010, Ukraine
}

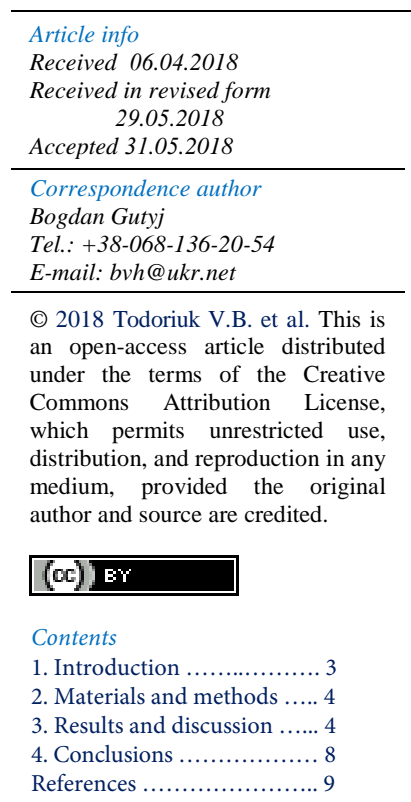

\begin{abstract}
The results of preclinical studies of the new ferrodextran preparation "Ferosel T", which contains ferrum and selenium, are presented. It has been established that at oral administration of ferrocellus $\mathrm{T}$ in a prophylactic dose of $2 \mathrm{ml} / \mathrm{kg}$ b.w. and the therapeutic dose of $4 \mathrm{ml} / \mathrm{kg}$ for 3 days in a row in the stomach of laboratory rats did not show toxic effects. No toxic effect of $\mathrm{T}$ ferrocellus is established at introducing it into the stomach in doses in 3 and 10 times higher than the therapeutic ones. Under conditions of subcutaneous administration of the drug, the death of white rats was not observed, only short-term inhibition of laboratory animals, which was prescribed the drug in a dose of $10 \mathrm{ml} / \mathrm{kg}$ b.w. It was established that in the preventive and optimal therapeutic doses the drug did not affect the detoxification function of the liver. In rats, which ferrocellus $\mathrm{T}$ was administered at maximum therapeutic and possibly toxic doses, the duration of hexenal sleep was for 32 and $35 \%$ higher relative to control values. The investigation of the emotional and behavioral reactions of laboratory animals after administration of ferrocellus $\mathrm{T}$ for 21 days in therapeutic and maximum therapeutic doses did not show a significant effect on the nervous system. In terms of hyperemia and swelling of the skin and the thickness of the skin, ferrocellus $\mathrm{T}$ in prophylactic and therapeutic doses upon application to rabbit skin did not cause local irritation. Separate injection of the drug "Ferosel T" by sub-planar way to guinea pigs in $0.1 \mathrm{ml}$. did not cause swollen reactions of the paws. As a result of the conducted research, no allergenic properties of the drug "Ferosel T" were found. In laboratory rats, which were introduced ferrosel $\mathrm{T}$ in the prophylactic dose of probable changes in the weight of the heart, liver, spleen and kidneys is not established. In rats, which were administered ferrocellus $\mathrm{T}$ in an optimal therapeutic dose, in comparison with control weights of the spleen and liver, respectively, was in 10.3 and $6.4 \%$ higher. When introducing ferrocellus $\mathrm{T}$ at the maximum therapeutic dose, the mass of the spleen and liver was in 14.0 and $15.0 \%$ higher, respectively. The results of the studies indicate that the drug "Ferosel $\mathrm{T}$ " is safe when used for the prevention and treatment of animals.
\end{abstract}

\section{Citation:}

Todoriuk, V.B., Hunchak, V.M., Gutyj, B.V., Gufriy, D.F., Hariv, I.I., Khomyk, R.I., \& Vasiv, R.O. (2018). Preclinical research of the experimental preparation "Ferosel T”. Ukrainian Journal of Veterinary and Agricultural Sciences, 1(1), 3-9.

\section{Introduction}

According to reports in the literature, with the intensive introduction of pigs on an industrial basis, in the absence of timely prophylactic measures, the disease of newborn piglets to ferrum-deficient anemia is $100 \%$, and death reaches 35\% (Zimmermann, 1995; Lee and Downing, 1979; Rytych et al., 2012; Ohorodnyk, 2013; Berezovskyi et al., 2013; Starzyński et al., 2013; Danchuk et al., 2013; Pu et al., 2015; Hunchak et al., 2018). In order to conduct the treatment and prevention of ferrum deficiency anemia of piglets, we have proposed a new ferro dextran drug "Ferosel T" (ferrocellus $\mathrm{T})$ - an analogue of the officinal preparation "Ferrovet $7.5 \%$ ", from which the ferrocellus- $T$ is different in the presence of sodium selenite in it (Todoriuk et al., 2016).

According to the Decree of the Department of Veterinary Medicine "Toxicological control of new means of animal protection”, approved by the Main Department of Veterinary Medicine of the Ministry of Agriculture and Food of
Ukraine as of December 16, 1996, each new preparation recommended for the treatment of animals must meet the following requirements:

- the new drug, in comparison with the analogue product, should exhibit higher therapeutic efficacy;

- it must not be toxic to the animals while it is used on them;

- the drug or its metabolites should not affect the sanitary quality and nutritional value of livestock products;

- in the manufacture and the use of the preparation, it should not cause harm to the environment.

For the treatment and prevention of ferrum deficiency anemia of piglets, we proposed a new saline ferro dextran drug "Ferosel T" - an analogue of the officinal preparation "Ferrovet 7.5\%", from which the ferrocellus $\mathrm{T}$ is different by the presence of sodium selenite (Todoriuk et al., 2016).

According to our requirements, we conducted experimental studies on acute and chronic toxicity (Gutyj et al., 
2017; 2018), pharmacological action and pharmacotherapeutic efficacy of ferrocellus $\mathrm{T}$ at spontaneous ferrum deficiency anemia of piglets.

Taking into account the fact that the toxicity of the components of the drug Ferosel $\mathrm{T}$, in particular Ferrum and Selenium, is already known and published in the literature (Gutyj et al., 2016; Khariv et al., 2016; Martyshuk et al., 2016; Khariv et al., 2017; Sobolev et al., 2018), we investigated the acute and chronic toxicity of Ferosel $\mathrm{T}$ as a whole, for oral and parenteral administration, and studied its effect on the detoxification function of the liver.

\section{Materials and methods}

Experiments on the determination of acute toxicity of ferrocellus $\mathrm{T}$ were performed on 50 laboratory rats (males and females) weighing 270-320 g. While using oral administration, the experiments were performed on 25 laboratory white rats, which were divided into 5 groups of 5 head in each. Ferrocellus $\mathrm{T}$ was injected to the experimental rats daily, 3 days in a row, with a metal probe through the mouth in prophylactic, therapeutic, maximal therapeutic and possibly toxic doses (Table 1). Rats of the control group (5 animals) were injected daily, during 3 days in a row, $15 \mathrm{ml} / \mathrm{kg}$ of isotonic sodium chloride solution into the stomach.

The experiments to determine the acute toxicity of ferrocellus $\mathrm{T}$ for parenteral administration were performed on 25 laboratory white rats, which were divided into 5 groups of 5 animals in each. Rats subcutaneously, daily for 3 consecutive days, were introduced ferrocellus $\mathrm{T}$ in the prophylactic, therapeutic, maximal therapeutic and possibly toxic doses.

The observation of laboratory animals were conducted for 7 days after the introduction of the drug. In the first day of the experiment, the animals were under constant surveillance. The following indicators were taken into account: general condition, appearance, intensity and character of mobile activity, coordination of movements, peculiarities of animal behavior, presence of a convulsions, reaction to external stimuli (tactile, sound, light), state of hair cover and visible mucous membranes, relation to forage, rhythm, frequency of breathing, time of occurrence and character of intoxication, its severity, course, time of death of animals or their recovery.

The influence of ferrocellus $\mathrm{T}$ on the detoxification function of the liver was studied in 20 white rats (males and females) weighing 270-320 g. The rats were divided into 4 groups (5 in each):

Rats of the first group (control) subcutaneously were injected isotonic sodium chloride solution in a dose of $6 \mathrm{ml} / \mathrm{kg}$ b.w.;

Rats of the second group $\left(D_{1}\right)$ subcutaneously were injected ferrocellus $\mathrm{T}$ in the prophylactic dose $-1 \mathrm{ml} / \mathrm{kg}$ b.w. (75 mg/kg of ferrum, $0.3 \mathrm{mg} / \mathrm{kg}$ of selenium);

Rats of the third group $\left(D_{2}\right)$ subcutaneously were injected ferrocellus $\mathrm{T}$ at a therapeutic dose of $2 \mathrm{ml} / \mathrm{kg} \mathrm{b.w.} \mathrm{(150}$ $\mathrm{mg} / \mathrm{kg}$ of ferrum, $0.6 \mathrm{mg} / \mathrm{kg}$ of selenium);

Fourth group rats (D3) subcutaneously were injected ferrocellus $\mathrm{T}$ at the maximum therapeutic dose of $6 \mathrm{ml} / \mathrm{kg} \mathrm{b.w}$. (450 mg/kg of ferrum, $1.8 \mathrm{mg} / \mathrm{kg}$ of selenium).

At 31st day since the start of the drug administration on 5 white rats from each group, the definition of the detoxifying function of the liver was determined using a hexenal test (Rozin, 1964). The laboratory animals received intraperitoneally $1 \%$ solution of hexenal in a dose of $45 \mathrm{mg} / \mathrm{kg}$ for this purpose. Then the average sleep time was recorded from the moment when the animal took a side position for sleep.

The irritant effect of ferrocellus $\mathrm{T}$ on the skin was studied on 12 rabbits. The skin was shaved equal $6 \mathrm{~cm}^{2}$ on the backs of animals and degreased with ethyl alcohol. Gauze tampon was rubbed in ferrocellus $\mathrm{T}$ in the skin using such doses: prophylactic $-1 \mathrm{ml} / \mathrm{kg}$ b.w. (first group), therapeutic optimal $-2 \mathrm{ml} / \mathrm{kg}$ (second group), therapeutic maximum - 6 $\mathrm{ml} / \mathrm{kg}$ (third group). Rats of the control group were rubbed in the isotonic sodium chloride solution at a dose of $6 \mathrm{ml} / \mathrm{kg}$. After 6, 24 and 48 hours after application of ferrocellus T, the irritating effect of the presence (absence) hyperemia and edema of the skin and skin fold thickness were determined, which is measured by a micrometer. Pain reaction of animals to the drug was determined by palpation of the place of application of "Ferosel” $\mathrm{T}$.

Experiments on the study of allergenic properties of ferrocellus $\mathrm{T}$ were carried out on guinea pigs weighing 500 $560 \mathrm{~g}$. Due to the lack of irritant effect of the ferrocellus $\mathrm{T}$, the testing of allergenic properties was performed by detecting itching and edema in the animals sensitized with this drug.

Guinea pigs ( $n=6$ ) were twice injected into a conjunctival sac of $0.05 \mathrm{ml}$ of "Ferosel” T. Control animals $(n=6)$ were injected with a sterile isotonic sodium chloride solution. 12 hours later. Repeatedly in a conjunctival sac, 0.05 $\mathrm{ml}$ of "Ferosel T" (test), isotonic sodium chloride solution (control) was cemented.

The irritant effect of the ferrocellus $\mathrm{T}$ on the mucous membrane of the eye was studied on 3 rabbits. In a conjunctival sac of the left eye, using the pipette animals were dipped in 2 drops of the drug. To control the right eye, animals were dipped in 2 drops of isotonic sodium chloride solution. The animal was fixed, the angle of the conjugate bag was pulled out and the tear-nasal duct was pressed over the finger for 1 minute. The irritant effect of ferrocellus $\mathrm{T}$ was determined by the presence (absence) of hyperemia of the conjunctiva, by the injection of blood vessels, by the state of sclera, cornea, and eyelids.

\section{Results and discussion}

Setting parameters of acute drug toxicity. Acute toxicity is a harmful effect of a drug that occurs after its single or repeated administration in short (at least 4 hours) intervals during the day.

During the study of acute toxicity of the drug "Ferosel $T$ ” it was necessary:

- to establish toxic doses or side effects of the drug for a single oral and parenteral administration in the prophylactic, therapeutic, maximum therapeutic, possibly toxic doses (Fig. 1);

- to investigate the effect of the newly developed drug at the indicated doses on the detoxification function of the liver by the method of "hexenal test".

Parameters of acute toxicity of ferrocellus $\mathrm{T}$ for introduction into the stomach of white rats are given in Table. 1.

Clinical observations of experimental and control rats were carried out for 7 consecutive days. During the trial period, clinical signs of toxic effects of the ferrocellus $\mathrm{T}$ in the doses studied by us have not been established in animals. The general condition of experimental animals was the same as in the control animals. Forage and water consumption were within normal limits. The faeces were without devia- 
tions from the normal consistency and smell. The reaction of animals to sound and tactile stimuli is adequate. There was no death of animals.

At day 7 of the experiment, the animals were decapitated at a light etheric anesthetic. At the section of the visible chang- es in the internal organs was not observed. Thus, the drug "Ferosel T" in prophylactic and therapeutic doses and in a dose of 3 times greater than the therapeutic, for oral administration to laboratory rats for 3 consecutive days did not show toxic effects.

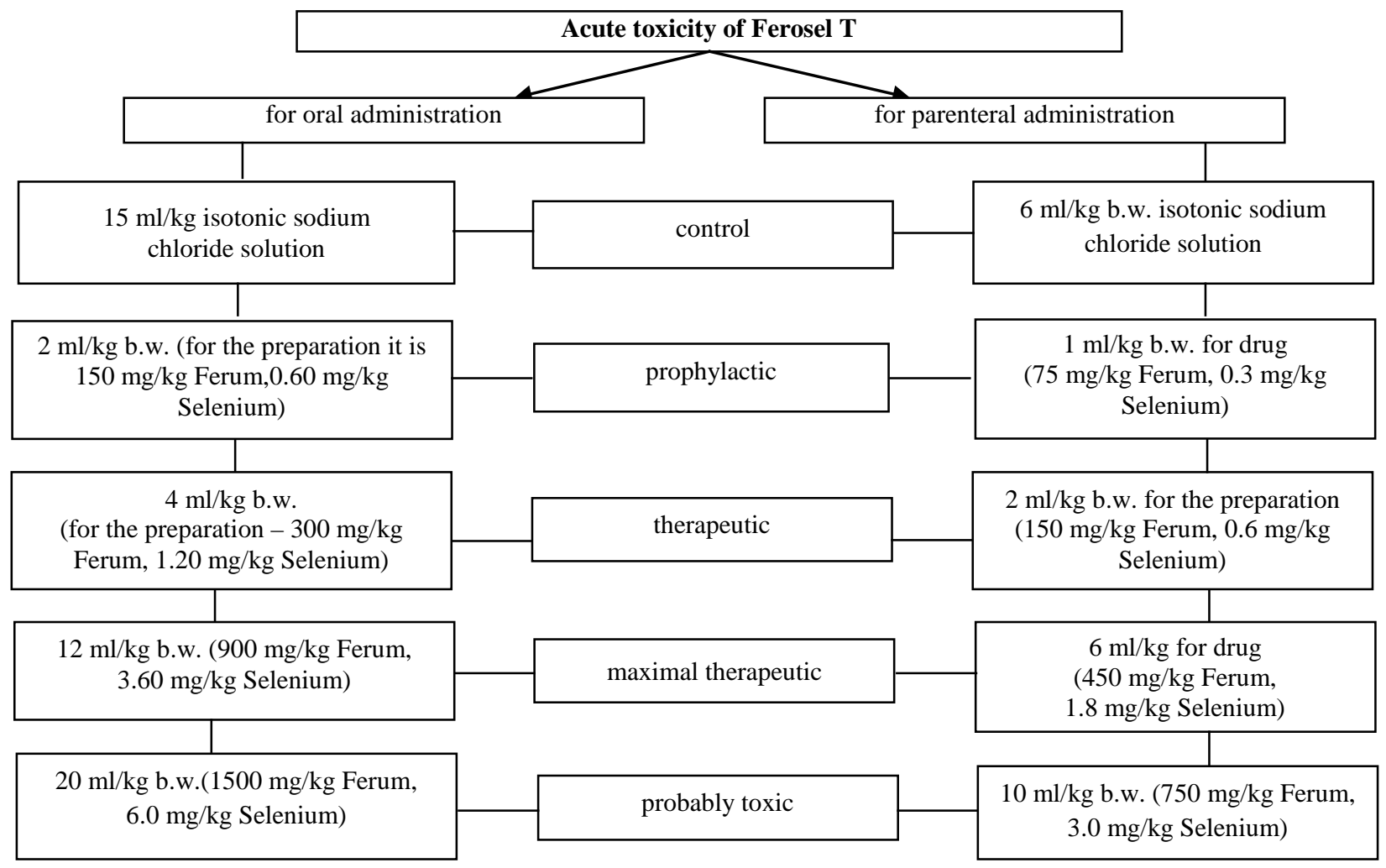

Fig. 1. The research to determine the acute toxicity

Table 1

Indicators of the preparation "Ferosel T" toxicity at the administration to stomach of white rats

\begin{tabular}{cccccc}
\hline \multirow{2}{*}{$\begin{array}{c}\text { Group of } \\
\text { animals }\end{array}$} & $\begin{array}{c}\text { Amount of animals in a } \\
\text { group }\end{array}$ & Preparation dose, $\mathrm{ml} / \mathrm{kg}$ & \multicolumn{3}{c}{ Amount of dead animals } \\
\cline { 5 - 6 } & 5 & - & total & in \% & 0 \\
Average time of death \\
\hline $\mathrm{D}_{1}$ & 5 & 2 & 0 & 0 & 0 \\
$\mathrm{D}_{2}$ & 5 & 4 & 0 & 0 & 0 \\
$\mathrm{D}_{3}$ & 5 & 12 & 0 & 0 & 0 \\
$\mathrm{D}_{4}$ & 5 & 20 & 0 & 0 & 0 \\
\hline
\end{tabular}

The next stage of the study was to determine the acute toxicity of ferrocellus $\mathrm{T}$ for parenteral administration to laboratory rats (Table 2).

It has been established that after subcutaneous administration in prophylactic and therapeutic doses, even at a dose that is in 3 times higher than the therapeutic, ferrocellus $\mathrm{T}$ did not show toxic effects on laboratory rats. The general condition, food intake and reaction to external stimuli in experimental animals were the same as in the control animals.

At day 7 of the experiment, the animals were decapitated using a slight etheric anesthesia. At the intersection of visible pathoanatomical changes in internal organs was not observed. In the injection site of the ferrocellus $\mathrm{T}$ the color- ing of the hypodermic tissue was light brown in color due to the presence of residual amounts of dextran that was not completely adsorbed.

Under conditions of subcutaneous administration, no death of white rats was observed, only the short-term inhibition of laboratory animals was observed, which was prescribed the preparation in a dose of $10 \mathrm{ml} / \mathrm{kg}$ bodyweight, which is due to the introduction into the body of a large amount of the drug, and in particular sodium selenite (Table 2).

Thus, in prophylactic, therapeutic doses and possibly toxic for a single dose subcutaneous injection for 3 consecutive days, ferrocellus $\mathrm{T}$ did not cause toxic effects on laboratory rats. 
Table 2

Indicators of the toxicity of the preparation "Ferosel $\mathrm{T}$ " at the subcutaneous injection to white rats

\begin{tabular}{cccccc}
\hline $\begin{array}{c}\text { Group of } \\
\text { animals }\end{array}$ & $\begin{array}{c}\text { Amount of animals in a } \\
\text { group }\end{array}$ & Preparation dose, $\mathrm{ml} / \mathrm{kg}$ & total & \multicolumn{2}{c}{ Amount of dead animals } \\
\cline { 4 - 6 } in \% & 0 & Average time of death \\
\hline $\mathrm{C}$ & 5 & - & 0 & 0 & 0 \\
$\mathrm{D}_{1}$ & 5 & 1 & 0 & 0 \\
$\mathrm{D}_{2}$ & 5 & 2 & 0 & 0 \\
$\mathrm{D}_{3}$ & 5 & 6 & 0 & 0 \\
$\mathrm{D}_{4}$ & 5 & 10 & 0 & 0 & 0 \\
\hline
\end{tabular}

Influence of "Ferosel $T$ " on the detoxification function of the liver. The liver plays an important role in many types of metabolism, protein synthesis, performs detoxification and excretory functions. By disposing of toxic substances, liver cells become the target of their action (Gutyj et al., 2017; Kryshtalska et al., 2017).
The influence of the ferrodextran preparations on the antitoxic function of the liver was studied by hexenal test. The basis of this method is the ability of various chemicals to influence the duration of hexenal sleep in laboratory animals, and as it is known, hexenal is completely metabolized in the liver.

Table 3

The length of the hexenal sleep in white rats after administration of Ferosel $T(M \pm m ; n=5)$

\begin{tabular}{clccc}
\hline $\begin{array}{c}\text { Group of } \\
\text { animals }\end{array}$ & \multicolumn{1}{c}{$\begin{array}{c}\text { Ferosel T } \\
(\text { dose })\end{array}$} & $\begin{array}{c}\text { Dose Fe } \\
(\mathrm{mg} / \mathrm{kg})\end{array}$ & $\begin{array}{c}\text { Dose Se } \\
(\mathrm{mg} / \mathrm{kg})\end{array}$ & Length of sleep (min) for: \\
\hline $\mathrm{C}$ & Control & - & - & $27,6 \pm 1.5$ \\
$\mathrm{D}_{1}$ & Prophylactic & 75 & 0.3 & $28,2 \pm 1.3$ \\
$\mathrm{D}_{2}$ & Therapeutic optimal & 150 & 0.6 & $27,8 \pm 1.5$ \\
$\mathrm{D}_{3}$ & Therapeutic maximal & 450 & 1.8 & $36.4 \pm 1.4^{*}$ \\
$\mathrm{D}_{4}$ & Possible toxic & 750 & 3.0 & $37.2 \pm 1.3^{* *}$ \\
\hline
\end{tabular}

Note: degree of probability: * $-\mathrm{P}<0.05 ; * *-\mathrm{P}<0.01$.

After the introduction of ferrocellus $\mathrm{T}$ at the indicated doses in the control and experimental groups, caused the pharmacological sleep by hypodermic hexenal injection at a dose of $60 \mathrm{mg} / \mathrm{kg}$ b.w.

It is known that the duration of hexenal sleep in animals depends on the ability of the microsomal liver enzymes to neutralize hexenal by means of glucuronization. Usually in clinically healthy rats, at a normal functional state of the liver, the sleep lasts 25-30 minutes.

The length of the animal's sleep was deducted from the moment they were taken by the side position to the first attempts to change it, and expressed in minutes.

It was found that after subcutaneous administration of ferrocellus $\mathrm{T}$, hexenal sleep in control and experimental rats $\left(\mathrm{C}, \mathrm{D}_{1}, \mathrm{D}_{2}\right)$ lasted from $27.6 \pm 1.5$ to $28.2 \pm 1.3 \mathrm{~min}$. Consequently, in the prophylactic and optimal therapeutic doses, the drug did not affect the detoxification function of the liver.

In rats of $\mathrm{D}_{3}$ and $\mathrm{D}_{4}$ groups, which were administered the ferrocellus $\mathrm{T}$ at maximum therapeutic and possibly toxic doses, the duration of hexenal sleep was in 32 and 35\% higher relative to control values. We believe that a longer sleep was a consequence of the toxic effects of sodium selenite on the liver. Selenium has a hepatotropic effect.

Determination of chronic toxicity of a ferrocellus $T$. The purpose of determining the chronic toxicity of a ferrocellus $\mathrm{T}$ is to detect the harmful effects of the drug in cases of its long-term administration into the body of experimental animals. In this case, it matters the detection of the most sensitive of its organs and systems, and the establishment of inverse recovery of functions against the background of the drug being studied.
After repeated administration, the drug may be irritant or cause allergic reactions, alter the functional state of the reproductive organs, affect the embryonic development of the fetus in the womb or show teratogenic or carcinogenic effects.

The toxicity of the ferrocellus $\mathrm{T}$ was studied according to the irritant action (skin and conjugate samples), the allergic action (skin application method), and the coefficients of the mass of the internal organs for long-term administration of the drug were determined.

During the period of research on the determination of chronic toxicity of ferrocellus $\mathrm{T}$, no probable changes in the behavior of experimental animals were observed (Table 4). The appetite of all experimental and control group of rats was satisfactory. In animals that were fed with ferrocellus $\mathrm{T}$ at a dose of $10 \mathrm{ml} / \mathrm{kg}$ for 21 days, motor activity decreased. Investigation of the emotional and behavioral reactions of laboratory animals after administration of ferrocellus $\mathrm{T}$ for 21 days in therapeutic and maximum therapeutic doses did not show a significant effect on the nervous system.

Under these conditions, a tendency towards inhibition was observed in animals receiving ferrocellus $\mathrm{T}$ in a dose of $10 \mathrm{ml} / \mathrm{kg}$, characterized by a decrease in motor activity (number of crossed squares), examination (number of standing poses), boobyme (number of washings). At the same time, the orientative-experimental (number of sniffs and glances) and emotional (number of defecations) reaction did not differ from that of all experimental groups $\left(D_{1}, D_{2}, D_{3}\right.$ and $\mathrm{D}_{4}$ ) and control group.

The clinical status of animals in the experimental and control groups in the course of the experiment remained within the limits of the physiological norm. 
Table 4

Indicators of the physiological state and activity of laboratory rats for 21 daily introduction of the ferrocellus $\mathrm{T}$ $(\mathrm{M} \pm \mathrm{m} ; \mathrm{n}=10)$

\begin{tabular}{ccccc}
\hline $\begin{array}{c}\text { Group of } \\
\text { animals }\end{array}$ & Preparation in a dose & Appetite & $\begin{array}{c}\text { Behavioral reaction (number of } \\
\text { holes that the animal sniffed) }\end{array}$ & $\begin{array}{c}\text { Vertical motor activity (number of } \\
\text { heights on the hind limbs) }\end{array}$ \\
\hline $\mathrm{C}$ & $\begin{array}{c}\text { (isotonic sodium chloride } \\
\text { solution } 6 \mathrm{ml} / \mathrm{kg})\end{array}$ & Sufficient & The hole reflex is saved & $10.20 \pm 0.51$ \\
$\mathrm{D}_{1}$ & $1 \mathrm{ml} / \mathrm{kg}$ & Sufficient & The hole reflex is saved & $10.65 \pm 0.50$ \\
$\mathrm{D}_{2}$ & $2 \mathrm{ml} / \mathrm{kg}$ & Sufficient & The hole reflex is saved & $10.70 \pm 0.45$ \\
$\mathrm{D}_{3}$ & $6 \mathrm{ml} / \mathrm{kg}$ & Sufficient & The hole reflex is saved & $9.98 \pm 0.60$ \\
$\mathrm{D}_{4}$ & $10 \mathrm{ml} / \mathrm{kg}$ & Sufficient & The hole reflex is saved & $9.57 \pm 0.62$ \\
\hline
\end{tabular}

\section{Table 5}

Characteristics of the local irritant action of the drug "Ferosel T", with a single effect on the skin of the rabbits $(\mathrm{M} \pm \mathrm{m} ; \mathrm{n}=3)$

\begin{tabular}{ccccc}
\hline \multirow{5}{*}{$\begin{array}{c}\text { Density of applica- } \\
\text { tion, ml/cm }\end{array}$} & \multicolumn{5}{c}{ Average mark of expressiveness } \\
\cline { 2 - 5 } & Group 1 & Group 2 & Group 3 & Group 4 \\
\hline \multicolumn{5}{c}{ swelling } \\
\hline 0.040 & 0 & 0 & 0 & 0 \\
0.060 & 0 & 0 & 0 & 0 \\
0.080 & 0 & 0 & 0 & 0 \\
0.100 & 0 & 0 & 0 & 0 \\
0.120 & 0 & 0 & 0 & 0 \\
\hline 0.020 & 0 & 0 & 0 & 0 \\
0.040 & 0 & 0 & 0 & 0 \\
0.060 & 0 & 0 & 0 & 0 \\
0.080 & 0 & 0 & 0 & 0 \\
0.100 & 0 & 0 & 0 & 0 \\
0.120 & 0 & 0 & 0 & 0 \\
\hline
\end{tabular}

Irritant effect of the drug "Ferosel T". It was established that the parameters of hyperemia and edema of the skin and the thickness of the skin folded ferrocellus $\mathrm{T}$ in prophylactic and therapeutic doses upon application to the rabbit skin did not cause local irritation (Table 5-6).

While studying the reaction of conjunctiva to ferrocellus T, after 30 min, 1, 3, 6, 12, 24 and 48 hours after instillation of the drug for the parameters we studied, the irritant effect of the ferrocellus $\mathrm{T}$ was not observed (Table 7).

Consequently, "Ferosel T" has no irritating properties when used externally.

Allergic properties of the drug "Ferosel T". Separate injection of "Ferosel T" subplanetary to guinea pigs $(n=6)$ in $0.1 \mathrm{ml}$ did not induce swelling of the paws, which differs from the similar reaction to the administration of isotonic sodium chloride solution $(n=6)$ (Table 8$)$.

As a result of the conducted research, no allergenic properties of the drug "Ferosel T" were found.

The experiment showed a lack of reaction of the conjunctiva of sensitized and intact guinea pigs in 1 and 24 hours for instillation of the drug (Table 8).

\section{Table 6}

The thickness of the skin folds of rabbits after application of the ferrocellus $T(M \pm m ; n=3)$

\begin{tabular}{|c|c|c|c|c|}
\hline \multirow{2}{*}{ № } & \multirow{2}{*}{$\begin{array}{l}\text { Group of animals } \\
\text { Ferosel-T (dose) }\end{array}$} & \multicolumn{3}{|c|}{ The thickness of the skin folds, mm } \\
\hline & & 6 hours & 24 hours & 48 hours \\
\hline 1 & Control (C) - 6 ml/kg b.w. (isotonic sodium chloride solution) & $2.04 \pm 0.03$ & $2.06 \pm 0.05$ & $2.07 \pm 0.04$ \\
\hline 2 & Prophylactic $\left(\mathrm{D}_{1}\right) 1 \mathrm{ml} / \mathrm{kg}$ b.w. & $2.08 \pm 0.03$ & $2.08 \pm 0.03$ & $2.07 \pm 0.05$ \\
\hline 3 & Therapeutic optimal $\left(\mathrm{D}_{2}\right) 2 \mathrm{ml} / \mathrm{kg}$ b.w. & $2.06 \pm 0.02$ & $2.06 \pm 0.03$ & $2.05 \pm 0.04$ \\
\hline 4 & Therapeutic maximal $\left(\mathrm{D}_{3}\right) 6 \mathrm{ml} / \mathrm{kg}$ b.w. & $2.03 \pm 0.05$ & $2.05 \pm 0.03$ & $2.06 \pm 0.04$ \\
\hline 5 & Probable toxic $\left(\mathrm{D}_{4}\right) 10 \mathrm{ml} / \mathrm{kg}$ b.w. & $2.05 \pm 0.04$ & $2.07 \pm 0.03$ & $2.06 \pm 0.03$ \\
\hline
\end{tabular}

\section{Table 7}

Influence of Ferosel T on Conjunctivitis, Cornea and Eyelid of the Rabbit's Eye $(M \pm m ; n=3)$

\begin{tabular}{|c|c|c|c|c|c|c|}
\hline \multirow{2}{*}{ Experiment time } & \multicolumn{2}{|c|}{ Rabbits of group № 1} & \multicolumn{2}{|c|}{ Rabbits of group № 2} & \multicolumn{2}{|c|}{ Rabbits of group № 3} \\
\hline & $\begin{array}{c}\text { Evaluation } \\
\text { in points }\end{array}$ & Irritant effect & $\begin{array}{c}\text { Evaluation } \\
\text { in points }\end{array}$ & Irritant effect & $\begin{array}{c}\text { Evaluation } \\
\text { in points }\end{array}$ & Irritant effect \\
\hline Before administration & 0 & Absent & 0 & Absent & 0 & Absent \\
\hline After 30 min. & 0 & Absent & 0 & Absent & 0 & Absent \\
\hline After 1 hours & 0 & Absent & 0 & Absent & 0 & Absent \\
\hline After 3 hours & 0 & Absent & 0 & Absent & 0 & Absent \\
\hline After 6 hours & 0 & Absent & 0 & Absent & 0 & Absent \\
\hline After 12 hours & 0 & Absent & 0 & Absent & 0 & Absent \\
\hline After 24 hours & 0 & Absent & 0 & Absent & 0 & Absent \\
\hline After 48 hours & 0 & Absent & 0 & Absent & 0 & Absent \\
\hline
\end{tabular}




\section{Table 8}

Frequency of detection of hypersensitivity in guinea pigs after intradermal administration of ferrocellus $\mathrm{T}$ by conjunctival test and swelling $(n=6)$

\begin{tabular}{cccc}
\hline \multirow{2}{*}{ Groups } & \multicolumn{3}{c}{ Conjunctival test } \\
\cline { 2 - 4 } & 0 & After 1 hour & After 24 hours \\
\hline Ferosel T & $6 / 6$ & $0 / 6$ & $0 / 6$ \\
$\begin{array}{c}\text { Isotonic solution of } \\
\text { sodium chloride }\end{array}$ & $6 / 6$ & $0 / 6$ & $0 / 6$ \\
& \multicolumn{3}{c}{ Swelling of the paws } \\
Ferosel T & $0 / 6$ & $6 / 6$ & $0 / 6$ \\
$\begin{array}{c}\text { Isotonic solution of } \\
\text { sodium chloride }\end{array}$ & $0 / 6$ & $6 / 6$ & $0 / 6$ \\
\hline
\end{tabular}

Influence of Ferosel $T$ on the coefficients of mass of internal organs. Experiments were performed on 25 laboratory rats weighing 270-320 g. Within 30 days, animals received ferrocellus $\mathrm{T}$ subcutaneously at intervals of 7 days
(4 injections) at the following doses: prophylactic - $1 \mathrm{ml} / \mathrm{kg}$ b.w., therapeutic optimum $-2 \mathrm{ml} / \mathrm{kg}$ Therapeutic maximum $-6 \mathrm{ml} / \mathrm{kg}$, possibly toxic $-10 \mathrm{ml} / \mathrm{kg}$. Rats of the control group, at intervals of 7 days, subcutaneously were injected isotonic sodium chloride solution in a dose of $6 \mathrm{ml} / \mathrm{kg}$.

During the animal experiment, clinical observations were performed. At the 30th day, the animals were decapitated using a light etheric anesthesia and the coefficients of the mass of the internal organs were determined (Table 9).

In laboratory rats, which received ferrocellus $\mathrm{T}$ in a prophylactic dose, in comparison with control probable changes in cardiac, liver, spleen, and kidney mass factors were not present.

In rats, which were administered ferrocellus $\mathrm{T}$ in an optimal therapeutic dose, in comparison with control weights of the spleen and liver, respectively, was in 10.3 and $6.4 \%$ higher. When administering ferrocellus $\mathrm{T}$ at the maximum therapeutic dose, the mass of the spleen and liver was in $14.0 \%$ and $15.0 \%$ higher respectively.

\section{Table 9}

The coefficients of the mass of the internal organs of the laboratory rats after the introduction of the ferrocellus $\mathrm{T}$ $(\mathrm{M} \pm \mathrm{m} ; \mathrm{n}=5)$

\begin{tabular}{llcccc}
\hline & \multicolumn{1}{c}{$\begin{array}{c}\text { Group of animals } \\
\text { Fo }\end{array}$} & \multicolumn{4}{c}{ Mass of the internal organs (g) } \\
\cline { 3 - 6 } & \multicolumn{1}{c}{ Ferosel-T (dose) } & Heart & Spleen & Liver & Kidneys \\
\hline 1 & Control (C) & $3.80 \pm 0.18$ & $3.30 \pm 0.15$ & $30.20 \pm 1.0$ & $7.34 \pm 0.25$ \\
2 & Prophylactic $\left(\mathrm{D}_{1}\right) 1 \mathrm{ml} / \mathrm{kg}$ & $3.76 \pm 0.10$ & $3.35 \pm 0.13$ & $30.15 \pm 1.1$ & $7.36 \pm 0.30$ \\
3 & Therapeutic optimal $\left(\mathrm{D}_{2}\right) 2 \mathrm{ml} / \mathrm{kg}$ & $3.78 \pm 0.15$ & $3.64 \pm 0.10^{* *}$ & $32.13 \pm 1.2$ & $7.32 \pm 0.20$ \\
4 & Therapeutic maximal $\left(\mathrm{D}_{3}\right) 6 \mathrm{ml} / \mathrm{kg}$ & $3.76 \pm 0.11$ & $3.76 \pm 0.16^{*}$ & $34.75 \pm 1.0^{* *}$ & $7.28 \pm 0.22$ \\
5 & Probable toxic $\left(\mathrm{D}_{4}\right) 10 \mathrm{ml} / \mathrm{kg}$ & $3.75 \pm 0.10$ & $3.81 \pm 0.12^{*}$ & $35.14 \pm 1.1^{* *}$ & $7.21 \pm 0.21$ \\
\hline
\end{tabular}

Note: The degree of probability in relation to control: * $-\mathrm{P}<0.05$, ** $-\mathrm{P}<0.01$.

The cardiac and kidney mass coefficients of the second and third group of rats did not indicate a probable difference with respect to control. We believe that after prolonged administration of "Ferosel T" to rats in therapeutic doses (optimal, maximal and possibly toxic), an increase in the mass of the liver and spleen occurred as a result of the strengthening of the functional state of these organs and the inflow of blood to them.

\section{Conclusions}

At the oral administration of ferrocellus $\mathrm{T}$ in a prophylactic dose of $2 \mathrm{ml} / \mathrm{kg}$ b.w.(which is Ferrum - $150 \mathrm{mg} / \mathrm{kg}$, Selenium $-0.6 \mathrm{mg} / \mathrm{kg}$ ) and a therapeutic dose of $4 \mathrm{ml} / \mathrm{kg}$ (Ferrum - $300.0 \mathrm{mg} / \mathrm{kg}$, Selenium - $1.2 \mathrm{mg} / \mathrm{kg}$ ) while administrating for 3 days in a row in the stomach of laboratory rats toxic effects do not appear. No toxic effect of the ferrocellus $\mathrm{T}$ has been established, as well as its introduction into the stomach in doses 3 and 10 times higher than the therapeutic ones.

While the subcutaneous administration of ferrocellus $\mathrm{T}$ during 3 days in a row in a prophylactic dose, optimal therapeutic, maximum therapeutic and in a dose in 5 times higher than the therapeutic, the drug did not cause toxic effects on laboratory rats.
In experiments with the determination of hexenal sleep, it was found that in preventive and optimal therapeutic doses, ferrocellus $\mathrm{T}$ did not affect the detoxification function of the liver. In the therapeutic maximum dose, the drug in the first 6 hours after administration slightly reduced the detoxification function of the liver due to sodium selenite, which at a dose of $1.2 \mathrm{mg} / \mathrm{kg}$ shows hepatotropic effect. 24 hours after the introduction of the ferrocellus $\mathrm{T}$, the detoxification function of the liver spontaneously completely restored.

In the study of chronic toxicity it has been established that ferrocellus $\mathrm{T}$ does not act irritatively on the skin and mucous membranes and does not show an allergic effect on the organism of animals after multiple applications.

In optimal and maximum therapeutic doses, Ferosel $\mathrm{T}$ increased by $14 \%$ the mass of the spleen, which occurred as a result of the activation of erythropoiesis in it, and increased the weight of the liver by $15 \%$ as a result of the strengthening of the Bilexynthesis function in it. Along with this, due to the strengthening of the functional state of these organs, there is an influx of blood, which also increases the mass of internal organs.

According to the classification of toxic substances (DOST 12.1.007-76), in terms of the degree of danger to animals, the Ferosel $\mathrm{T}$ as a whole and its component, ferrum sulfate, are classified as toxic grade 4 (low toxicity substances). The second component of the Ferosel $\mathrm{T}$ - sodium 
selenite is classified as grade 4 toxicity (moderately toxic substances).

Acknowledgments: authors of the article would like to express the words of gratitude to Mykhailo Podoliak for his assistance in translating the article and reviewing it for language mistakes.

\section{References}

Berezovskyi, R.Z., Maksymovych, I.Ia., \& Vlizlo, V.V. (2013). Vmist okremykh mikroelementiv u krovi porosiat za umov vnutrishnomiazovoho vvedennia yim riznykh doz ferum tsytratu. Veterynarna medytsyna, 97. 304-307. Rezhym dostupu: http://nbuv.gov.ua/UJRN/vetmed_2013_97_120 (in Ukrainian).

Danchuk, V.V., Prystupa, T.I., \& Polishchuk, O.I. (2013). Dynamika kholesterolu lipoproteidiv u krovi porosiat-sysuniv pry vvedenni preparativ Fe. Veterynarna biotekhnolohiia, 22, 117-122. Rezhym dostupu: http://nbuv.gov.ua/UJRN/ vbtb_2013_22_24 (in Ukrainian).

Gutyj, B., Grymak, Y., Hunchak, V., Mysak, A., Nazaruk, N., Brezvyn, O., Hariv, I., Shcherbatyy, A., Semeniv, B., Bushueva, I., Parchenko, V., \& Kaplaushenko, A. (2018). Preclinical searches of the preparation Thireomagnile. Ukrainian Journal of Ecology, 8(1), 688-695. doi: 10.15421/2018_267.

Gutyj, B., Khariv, I., Binkevych, V., Binkevych, O., Levkivska, N., Levkivskyj, D., \& Vavrysevich, Y. (2017). Research on acute and chronic toxity of the experimental drug Amprolinsyl. Regul. Mech. Biosyst., 8(1), 41-45. doi: 10.15421/021708.

Gutyj, B., Martyshchuk, T., Bushueva, I., Semeniv, B., Parchenko, V., Kaplaushenko, A., Magrelo, N., Hirkovyy, A., Musiy, L., \& Murska, S. (2017). Morphological and biochemical indicators of blood of rats poisoned by carbon tetrachloride and subject to action of liposomal preparation. Regulatory Mechanisms in Biosystems, 8(2), 304-309. doi: 10.15421/021748.

Gutyj, B., Paska, M., Levkivska, N., Pelenyo, R., Nazaruk, N., \& Guta, Z. (2016). Study of acute and chronic toxicity of 'injectable mevesel' investigational drug. Biological Bulletin of Bogdan Chmelnitskiy Melitopol State Pedagogical University, 6(2), 174-180. doi: 10.15421/201649.

Hunchak, R.V., Sedilo, H.M., Kystsiv, V.O., Gutyj, B.V., \& Hunchak, V.M. (2018). Total liquid maintenance and correlation of their classes in the sow's colostrum and milk at different levels of aquacart of Iodine in their rations. Ukrainian Journal of Ecology, 8(1), 644-648. doi: 10.15421/2017_261.

Khariv, M., Gutyj, B., Butsyak, V., \& Khariv, I. (2016). Hematological indices of rat organisms under conditions of oxidative stress and liposomal preparation action. Biological Bulletin of Bogdan Chmelnitskiy Melitopol State Pedagogical University, 6 (1), 276-289. doi: 10.15421/201615.

Khariv, M., Gutyj, B., Ohorodnyk, N., Vishchur, O., Khariv, I., Solovodzinska, I., Mudrak, D., Grymak, C., \& Bodnar, P.
(2017). Activity of the T- and B-system of the cell immunity of animals under conditions of oxidation stress and effects of the liposomal drug. Ukrainian Journal of Ecology, 7(4), 536-541. doi: 10.15421/2017_157.

Kryshtalska, M., Hunchak, V., \& Gutyj, B. (2017). Influence of the drug «Trifuzol» on the functional state of the liver in chickens for eymeriozic invasion. Scientific Messenger LNUVMBT named after S.Z. Gzhytskyj, 19(77), 76-79. doi: 10.15421/nvlvet7718.

Lee, J.C., \& Downing, S.E. (1979). Effects of anemia and growth retardation on respiratory activity in the piglet. Biol Neonate, 36(5-6), 255-263. doi: 10.1159/000241237.

Martyshuk, T.V., Gutyj, B.V., \& Vishchur, O.I. (2016). Level of lipid peroxidation products in the blood of rats under the influence of oxidative stress and under the action of liposomal preparation of «Butaselmevit», Biological Bulletin of Bogdan Chmelnitskiy Melitopol State Pedagogical University, 6(2), 22 27. doi: 10.15421/201631.

Ohorodnyk, N.Z. (2013). Vplyv kompleksnoho liposomalnoho preparatu na hematolohichnyi profil krovi vidluchenykh porosiat. Svynarstvo, 62, 135-140. Rezhym dostupu: http://nbuv.gov.ua/UJRN/svun_2013_62_31 (in Ukrainian).

Pu, Y., Guo, B., Liu, D., Xiong, H., Wang, Y., \& Du, H. (2015). Iron Supplementation Attenuates the Inflammatory Status of Anemic Piglets by Regulating Hepcidin. Biol Trace Elem Res., 167(1), 28-35. doi: 10.1007/s12011-015-0295-6.

Rozin, D.G. (1964). Modern evaluation of toxicity chlorproductive carbohydrates of fatty raw yder gexanal test with white mice. Pharmacology and toxicology. 5, 613-614.

Rytych, J.L., Elmore, M.R., Burton, M.D., Conrad, M.S., Donovan, S.M., Dilger, R.N., \& Johnson, R.W. (2012). Early life iron deficiency impairs spatial cognition in neonatal piglets. $J$ Nutr., 142(11), 2050-2056. doi: 10.3945/jn.112.165522.

Sobolev, O., Gutyj, B., Petryshak, R., Pivtorak, J., Kovalskyi, Y., Naumyuk, A., Petryshak, O., Semchuk, I., Mateusz, V., Shcherbatyy, A., \& Semeniv, B. (2018). Biological role of selenium in the organism of animals and humans. Ukrainian Journal of Ecology, 8(1), 654-665. doi: 10.15421/2017_263.

Starzyński, R.R., Laarakkers, C.M., Tjalsma, H., Swinkels, D.W., Pieszka, M., Styś, A., Mickiewicz, M., \& Lipiński, P. (2013). Iron supplementation in suckling piglets: how to correct iron deficiency anemia without affecting plasma hepcidin levels. PLoS One, 8(5), e64022. doi: 10.1371/journal.pone.0064022.

Todoriuk, V.B., Gutyj, B.V., Khomyk, R.I., \& Vasiv, R.O. (2016). Influence of ferrovet $7.5 \%$ and ferosel $\mathrm{T}$ on the concentration of mineral substances in the blood serum of piglets suffering from Iron deficit anemia. Scientific Messenger LNUVMBT named after S.Z. Gzhytskyj, 18, 3(71), 139-143. doi: 10.15421/nvlvet7131.

Zimmermann, W. (1995). Effects of different anemia prevention forms on the blood parameters of the suckling piglet. Dtsch Tierarztl Wochenschr, 102(1), 32-38. https://www.ncbi.nlm.nih.gov/pubmed/7781536. 